\title{
Problem Based Learning: Practicing Students' Critical Thinking Skills with Cognitive Style Dependent Fields and Independent Fields
}

\author{
Wahyu Listiagfiroh ${ }^{1, a)}$, Ellianawati ${ }^{2, b)}$ \\ ${ }^{1}$ Program Studi Magister Pendidikan Fisika, Pascasarjana, Universitas Negeri Semarang \\ ${ }^{2}$ Jurusan Fisika Fakultas Matematika dan Ilmu Pengetahuan Alam, Universitas Negeri Semarang

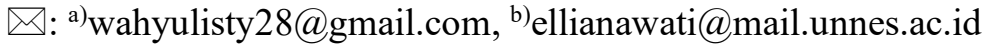

\begin{abstract}
The critical thinking skills require to be possessed by students to decide to gain new knowledge. The perception differences by each student influence students' thinking skills have, so to practice these skills is a needed learning approach to the student truly. One of them is problem-based learning. The purpose of this study is to train students' critical skills who have the cognitive method of Field Independent (FI) and Field Dependent (FD). This type of research is experimental research. The sampling technique in this study uses a cluster random sampling technique, which is taking random group samples. The results of this study are (1) the average Islamic Nurul Hadi Vocational School students belong to the dependent field cognitive style (FD); (2) the majority of students' critical thinking skills are in the high category, in 26 students consisting of 19 FI students and 7 FD students; (3) FI students are better at critical thinking compared to FD students. FD students need guidance in solving problems. PBL learning model is very appropriate to be used to train students' critical thinking skills with different cognitive styles.
\end{abstract}

Keywords: problem-based learning, critical thinking skills, cognitive style

\section{INTRODUCTION}

The 2013-Curriculum is a curriculum that prioritizes understanding, skill, and character education. Students are required to understand the material, be active in discussions and presentations and have high discipline manners. The 2013-Curriculum has three aspects of assessment, namely aspects of knowledge, aspects of skills, and aspects of attitude and behavior. The 2013-Curriculum addresses the characteristics of the community being able to face challenges through learning. Science physics learning is oriented towards developing strategies and solutions to solving problems in everyday life (Nugraha et al., 2017).

Educational unit level curriculum development is based on the principle that students have a central position to develop their abilities or skills (Purnomo et al., 2017). One of these skills is critical thinking skills. Critical thinking skills are analytical thinking that can be used to produce different solutions (Bergili, 2015).

Related to the rapid development of technology and the lack of assistance from parents, critical thinking skills are needed for students to filter and process information obtained from information, both in the school environment and the community (Nisak et al., 2015). Critical thinking skills need to be developed by students in order to survive and follow various forms of increasingly competitive changes (Purnomo et al., 2017), to be used to make strong decisions to obtain new knowledge (Fuad et al., 2017). According to Nugraha's research results (2017), students' critical thinking skills have improved 
by applying PBL models, science process skills have an influence on critical thinking skills, and high learning motivation affects high critical thinking skills. So in this study wanted to know the students' critical thinking skills with different cognitive styles possessed by students.

According to Lloyd and Bahr (2010), each student has a different perception regarding high-level thinking. Every student has different characteristics of learning. Students generally show different responses when faced with the same learning situations and conditions (Nugraha et al., 2016). Every student has the ways he likes in compiling what he sees, remembers and thinks about. Differences between settled individuals in how to compile and process information and experiences are known as cognitive styles (Slameto, 2010).

The cognitive style was divided into two, namely field independent (FI) and filed dependent (FD). Someone with FI rendering states that a picture is free from the background of the picture, and can distinguish objects from the surrounding contours more easily. Whereas someone with FD receives something more globally and has difficulty in separating himself from his surroundings, FDs tend to know him as part of a group. (Slameto, 2010). In research conducted by Umbrella et al. (2017) shows that the TGT learning model is suitable for FI students, but not suitable for FD students. FI is more comfortable with active learners, whereas FD learning is following the teacher's direction. So that in this study, we want to apply a different learning model that is problem-based learning.

Based on the problems described above, there needs to be an effort to train students' critical thinking skills related to differences in the cognitive styles of students. One of them is by choosing the right learning model. In addition to practicing critical thinking skills, a learning approach is needed that involves students more actively in the learning process. Everything can be realized through a form of learning that is designed in such a way that can reflect student involvement actively in instilling cognitive awareness (Noordyana, 2016). One of the appropriate learning models to train critical thinking skills is the Problem Based Learning model (Umuroh and Agoestanto, 2016). Students learn to solve new problems and to reflect on their experiences when student-centered learning methods are used (Ulger, 2018). PBL is a learner-centered pedagogical approach that gives students (including certified teacher candidates) opportunities to engage in purpose-directed investigations (Simone, 2014).

A problem-based learning model is a teaching approach where the teacher gives students a problem for students to solve independently. Several previous studies have shown that problem-based learning can improve various learning outcomes (Malik 2015, Nurhayati et al. 2017, Fathiah et al. 2015, Sari et al. 2015, Bakri et al. 2018, Halim et al. 2017). Problem Based Learning is one part of problem-solving learning involving students in teaching and learning activities. In many studies relative to collaboration and critical thinking, a learning strategy called Based Learning has proven to be an effective approach to teaching and learning (Styron, 2014). Learning with this model is expected to be able to improve the critical thinking skills of students who have different cognitive styles.

\section{METHODS}

This research is an experimental study that aims to train the critical thinking skills of students who have the cognitive style of the Independent Field (FI) and Field Dependent (FD). The sample in this study were students of Islamic Vocational School Nurul Hadi Batu Karangengah Demak. The sampling technique in this study uses a cluster random sampling technique, which is to take group samples randomly to obtain a sample of 40 students.

The instrument in this study consisted of a matter of GEFT (Group Embedded Figures Test). GEFT is a test where each individual is directed to look for a series of simple forms that are in a complex and larger form, designed in such a way as to include or hide these simple forms (Suryanti, 2014). This test consists of 3 parts, the first part consists of 7 questions which only function as exercises so that the results are not taken into account. The second and third sections consist of 9 questions, each of which is given a score of 1 for the correct answer and 0 for the wrong answer so that the maximum score of the test is 18 and at least 0 . In addition to using the GEFT problem, the data collection technique is also done using a test sheet in the form of essays (descriptions) as many as five items are used to measure students' critical skills. 
From the results that have been obtained will be analyzed by data triangulation techniques that are reducing data, data exposure, and making conclusions. Reducing data is choosing the main things, simplifying and removing unnecessary. Data exposure is carried out after reducing the data, which includes the classification and identification of data. The presentation of data is done in the form of brief descriptions, charts, and relationships between categories. Making conclusions in this study is a new finding that can interpret the situation in the class being observed. This finding is in the form of a description or description of an object that was previously still vague, then examined to be clear.

TABLE 1. The Grid of Test Instruments

\begin{tabular}{lll}
\hline \multicolumn{1}{c}{ Test } & \multicolumn{1}{c}{ Indicator } & \multicolumn{1}{c}{ Question number } \\
\hline Critical thinking & $\begin{array}{l}\text { Provide a simple explanation of } \\
\text { the conversion of temperature } \\
\text { measurement scales }\end{array}$ \\
& $\begin{array}{l}\text { Provide a further explanation } \\
\text { about measurements using a } \\
\text { thermometer } \\
\text { Set strategies and tactics in } \\
\text { calculating the conversion scale } \\
\text { of temperature measurements } \\
\text { with different thermometers }\end{array}$ \\
\hline Question Total & \multicolumn{2}{c}{5} \\
\hline
\end{tabular}

\section{RESULTS AND DISCUSSION}

Based on the research conducted by Suryanti (2014), it was explained that the assessment using GEFT with values 0 - 11 belonged to the Dependent (FD) field category and the 12-18 values belonged to the field independent (FI) category. The GEFT test results conducted on Nurul Hadi Islamic Vocational School students showed that students who had field-independent cognitive style (FI) were 47.5\% (19 students) and students who had a field-dependent (FD) cognitive style of $52.5 \%$ (21 students). This shows that the sample in this study had an almost balanced cognitive style. The cognitive style possessed by students is used as an important factor to differentiate the way students get and process information.

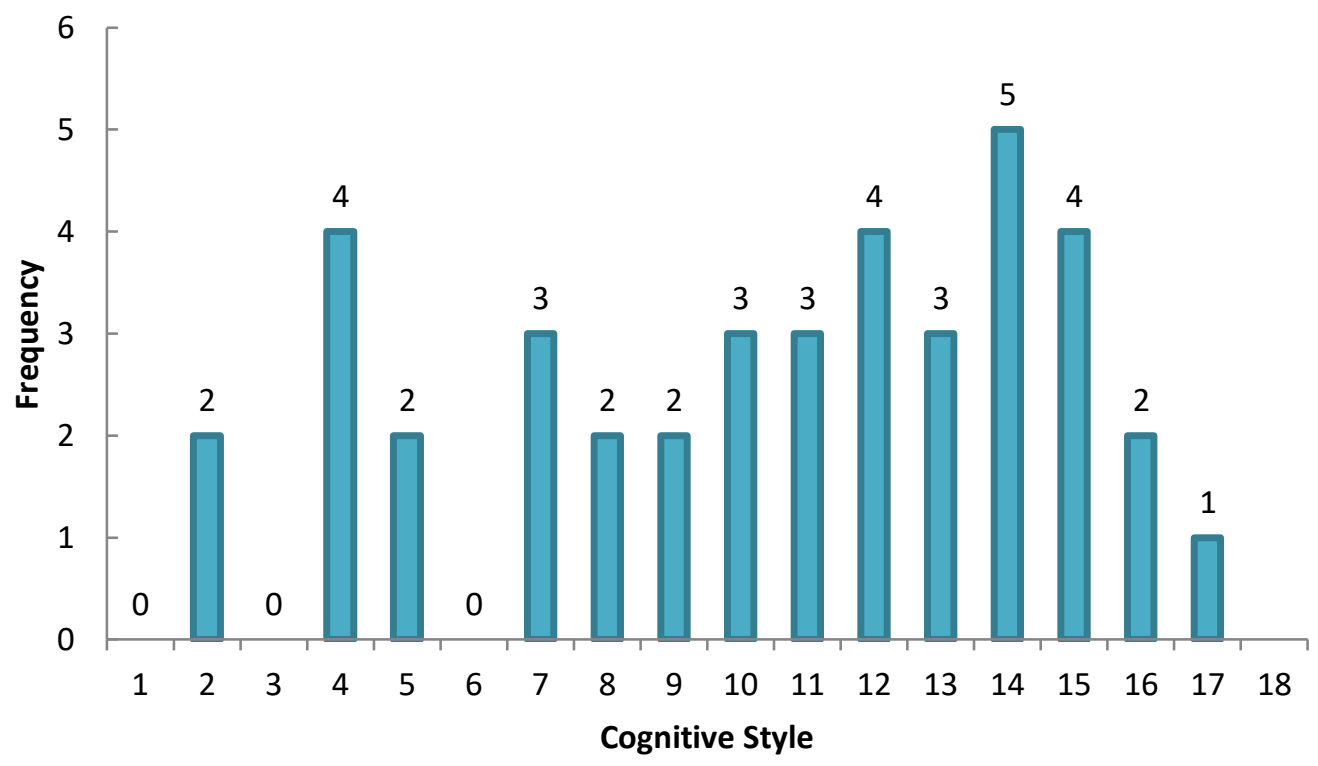

FIGURE 1. The result of cognitive style of students. 
The data in FIGURE 1 shows that the most dominant score is 14 in the FI category as many as five students, the lowest score is 2 in the Fd category as many as two students, and the highest score is 17 as one student. The student's average cognitive style score is 10.35 . This shows that the majority sample is in the Field Dependent category.

Different cognitive styles will have an impact on students' critical thinking skills. Critical thinking is reflective and reasonable thinking and focuses on determining what must be done and trusted (Winarso and Dewi, 2017). Based on research conducted by Nugraha et al. (2017) students' critical thinking skills are grouped into 3 categories, namely, high categories if they are at 67-100 percent, medium category if they are in the percentage of 34-67, and low categories if they are in the percentage $0-34$.

TABLE 2. Levels of Critical Thinking Skills

\begin{tabular}{lll}
\hline Percentage $(\%)$ & Categories & Number of Students \\
\hline $67 \leq \mathrm{x} \leq 100$ & High & 26 \\
$34 \leq \mathrm{x} \leq 67$ & Average & 5 \\
$0 \leq \mathrm{x} \leq 34$ & Low & 9 \\
\hline
\end{tabular}

The data obtained in this study is the data value of students' critical thinking skills after being treated with the problem-based learning model in the heat temperature material. Based on the data contained in Table. 2 students with high critical skill levels were 26 students consisting of 19 field independent students (FI) and seven field-dependent (FD) students. Middle and low-level students come from field independent students (FI). This shows that the problem-based learning model successfully trains students to think critically even though only $33.3 \%$ of independent field students are at the high category level, and $23.8 \%$ in the moderate category, while the others are in a low category.

Physics is one type of subject that is analytical and requires good problem-solving skills; many studies have shown that the learning outcomes of field-independent students will be better than fielddependent students. This is because field independent students (FI) are able to analyze well as done by (Akramunnisa and Sulestry, 2014).

Field dependent students (FD) tend to like lessons in the form of social material, the learning process must be accompanied by experience and there must be guidance or organization from the teacher. To train students in critical thinking skills in physics subjects, field-dependent students (FD) need learning that involves the student being active and guided. A suitable approach can train students' critical thinking skills. The learning model chosen in this study is the Problem-based learning model with the help of PPT media and student worksheets accompanied by teacher guidance.

Problem Based Learning is a student-centered learning model that emphasizes students to play an active role. PBL is implemented by giving problems to students to be solved in groups or discussions. In the discussion process, the teacher acts as a supervisor so that this model is suitable for students who have a field-dependent (FD) cognitive style and LKS facilities that contain analytical problems in PBL learning suitable for students who have cognitive field independent (FI). 


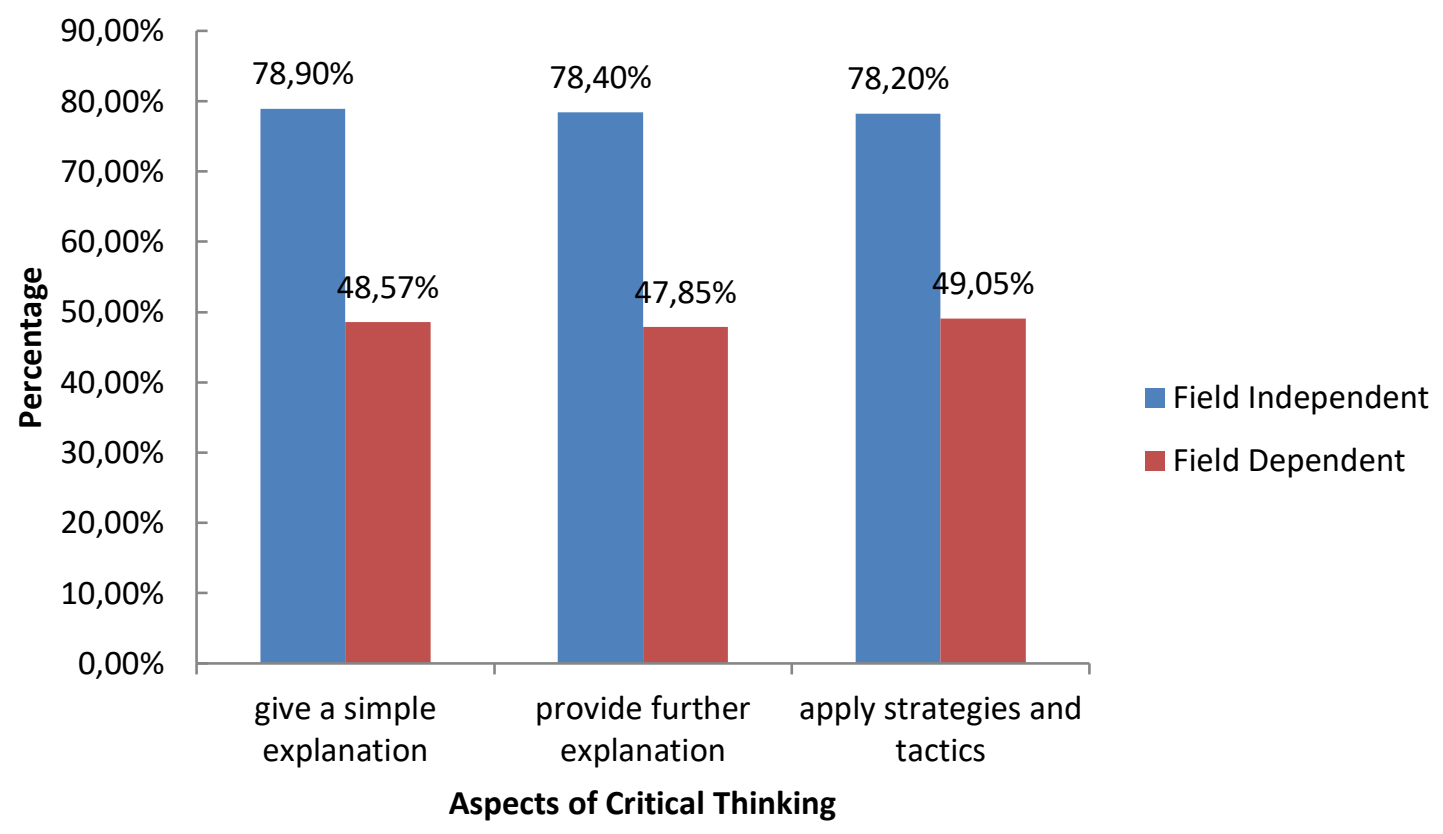

FIGURE 2. The comparison of students' critical thinking.

According to Ennis (Umuroh and Agoestanto, 2016) that critical thinkers have 12 critical thinking skills grouped into five aspects, including:

TABLE 3. Indicators of Critical Thinking Skills

\begin{tabular}{ll}
\hline Critical thinking & Critical Sub Indicator \\
\hline Give a simple explanation & 1. Focusing on questions \\
& 2. Analyze opinions \\
3. Clarify the explanation through question & and answer \\
Determine the basis for decision making & 1. Consider whether the source can be \\
trusted or not and considering \\
Draw a conclusion & 2. Observing abservational reports \\
& 1. Reducing and considering the results of \\
& 2. Induce and consider the results of \\
Provide further explanation & 3. Make and determine value \\
Implement strategies and tactics & 1. Define the term and consider the \\
& 2. Identifying assumptions \\
& 1. Determine action \\
& 2. Interacting with other people
\end{tabular}

In this study, only three aspects of thinking ability will be used, namely giving a simple explanation, giving further explanation, and applying strategies and tactics.

In FIGURE 2 the results show that FI students have good critical thinking skills compared to FD students. This is in accordance with the research conducted by Purnomo et al. (2017) that FI students are better at solving problems, they use a variety of ways to solve problems. When working on the students' skills, the FI concentrates fully so that a satisfactory answer is generated. FD students in 
solving problems show less seriousness. FD students still need more guidance in solving problems either by the teacher or friends.

\section{SUMMARY}

Based on the results of the analysis of critical thinking skills in terms of the cognitive fieldindependent and field-dependent styles, it can be concluded that the average student cognitive style score is 10.35. This shows that the majority of Nurul Hadi Islamic Vocational School students have the FD style cognitive. Based on the percentage of GEFT test results, students with FI cognitive styles were $47.25 \%$ and students with FD cognitive style were $52.75 \%$.

The level of students' critical thinking skills is in the high category of 26 students from 40 students, consisting of $19 \mathrm{FI}$ students and $7 \mathrm{FD}$ students. This shows that by applying the problem-based learning model can train students' critical thinking skills.

FI students have better critical thinking skills than FD students. FI students can use various ways to solve problems, while FD students need guidance to solve problems. Therefore, the application of PBL is very suitable to train students' critical thinking skills with differences in cognitive style.

\section{REFERENCES}

Akrumunnisa, A, Sulestry, S \& Indra, A 2014, 'Analisis Kemampuan Menyelesaikan Masalah Matematika Ditinjau Dari Kemampuan awal Tinggi dan Gaya Kognitif Field Independent (FI)', Jurnal Pedagogy, vol. 1, no. 2.

Bakri, F, Sunaryo, S, Irawan, VF \& Muliyati, D 2018 'E-Learning Model for Problem Based Learning on Heat and Thermodynamic Topics in High School', Jurnal Penelitian \& Pengembangan Pendidikan Fisika, vol. 4, no. 2.

Birgili, B 2015, 'Creative and Critical Thinking Skills in Problem-based Learning Environments', Journal of Gifted Education and Creativity, vol. 2, no. 2.

Fathiah, F, Kaniawati, I \& Utari, S 2015, 'Analisis Didaktik Pembelajaran yang Dapat Meningkatkan Korelasi antara Pemahaman Konsep dan Kemampuan Pemecahan Masalah Siswa SMA pada Materi Fluida Dinamis', Jurnal Penelitian \& Pengembangan Pendidikan Fisika, vol. 1, no. 1.

Fuad, NM, Zubaedah, S, Mahanal, S \& Suarsini, E 2017, 'Improving Junior High Schools' Critical Thinking Skills Based on Test Three Different Models of Learning', International Journal of Instruction, vol. 10, no. 1.

Halim, A, Suriana, S \& Mursal, M 2017, 'Dampak Problem Based Learning terhadap Pemahaman Konsep Ditinjau dari Gaya Berpikir Siswa pada Mata Pelajaran Fisika', Jurnal Penelitian \& Pengembangan Pendidikan Fisika, vol. 3, no. 1.

Lloyd, M \& Bahr, N 2010, 'Thinking Critcally about Critical Thinking in Higher Education', International Journal For the Scholarship of Teaching and Learning, vol. 4, no. 2.

Malik, A 2015, 'Model Pembelajaran Problem Based Instruction untuk Meningkatkan Penguasaan Konsep dan Keterampilan Proses Sains Mahasiswa', Jurnal Penelitian \& Pengembangan Pendidikan Fisika, vol. 1, no. 1.

Nisak,SK \& Hadi, S 2015, 'Analisis Proses Berpikir Kritis Siswa dalam Menyelesaikan Soal Peluang', Prosiding Seminar Nasional Pendidikan Matematika (Semnasdikta) IAIN Tulungagung, pp. 208219.

Noordyana, MA 2016, 'Meningkatkan Kemampuan Berpikir Kritis Matematis Siswa melalui Pendekatan Metacognitive Instruction', Jurnal Mosharofa, vol. 5, no. 2.

Nugraha, AJ, Suyitno, H \& Susilaningsih, E 2017, 'Analisis Kemamouan Berpikir Kritis Ditinjau dari keterampilan Proses Sains dan Motivasi Belajar melalui Model PBL', Journal of Primary Education, vol. 6 no. 1. 
Nurhayati, N \& Angraeni, L 2017, 'Analisis Kemampuan Berpikir Tingkat Tinggi Mahasiswa (Higher Order Thinking) dalam Menyelesaikan Soal Konsep Optika melalui Model Problem Based Learning', Jurnal Penelitian \& Pengembangan Pendidikan Fisika, vol. 3, no. 2.

Payung, MSB, Nuriah, T \& Sarkadi, S 2017, 'Pengaruh Model Pembelajaran Dan Gaya Kognitif Terhadap Hasil Belajar Sejarah Siswa di SMA 28 Kab. Tangerang', Jurnal Pendidikan Sejarah, vol. 6 , no. 1.

Purnomo, RC, Sunardi, S \& Sugiarti, T 2017, 'Profil Kreativitas dalam Pemecahan Masalah Matematika ditinjau Dari Gaya Kognitif Field Independent (FI) dan Field Dependent (FD) Siswa kelas VIII A SMP Negeri 12 Jember', Jurnal Edukasi, vol. IV, no. 2.

Sari, AP, Feranie, S \& Karim, S 2015, 'Penerapan Pembelajaran Berbasis Masalah dengan Pendekatan Multirepresentasi untuk Meningkatkan Prestasi Belajar dan Konsistensi Ilmiah Berbasis Multirepresentasi pada Materi Elastisitas', Jurnal Penelitian \& Pengembangan Pendidikan Fisika, vol. 1 , no. 2 .

Simone, C D 2014, 'Problem- Based Learning in Teacher Education: Trajectories of Change', International Journal of Humanities and Social Science, vol. 4, no. 12.

Slameto, S 2010, 'Belajar dan Faktor-faktor yang mempengaruhinya', Jakarta: Rineka Cipta.

Styron, RA 2014, 'Critical Thinking and Collaboration: A Strategi to Enhance Student Learning', Systemics, Cybernetics and Informatics, vol. 12, no. 7.

Suryanti, N 2014, 'Pengaruh gaya Kognitif Terhadap Hasil Belajar Akuntansi Keuangan Menengah 1', Jurnal Ilmiah Akuntansi dan Humanika, vol. 4 no. 1.

Ulger, K 2018, 'The Effect of Problem- Based Learning on the Creative Thinking and Critical Thinking Disposition of Student in Visual Arts Education', Interdisciplinary Journal of Problem Based Learning, vol. 12, no. 1.

Umuroh, K \& Agoestanto, A 2016, 'Implementasi Model Pembelajaran PBL terhadap Kemampuan Berpikir Kritis dan Kedisiplinan Siswa', Seminar Nasional Matematika X Universitas Negeri Semarang 2016, pp. 532-538.

Winarso, W \& Dewi, WY 2017, 'Berpikir Kritis Siswa Ditinjau Dari Gaya Kognitif Visualizer dan Verbalizer dalam Menyelesaikan Masalah Geometri', Beta Jurnal Tadris Matematika, vol. 10, no. 2. 
